\title{
The Impact of Information and Communication Technology (ICT) and The Challenge of Civic Education
}

\author{
Rini Triastuti \\ Civic Education \\ Surakarta, Indonesia \\ rini_triastuti_yk@yahoo.com
}

\begin{abstract}
This article is intended to describe the impact of information and communication technologies on the behavior of Indonesian citizens. We know that the information and communication technology is growing very rapidly and effect on all aspects of life. In recent times citizens are not only faced the real world but also cyberspace. Converge between citizens and the technology has caused a tremendous impact. Technology not only caused positive impact, but also caused negative impact. This study is a literature study. Data shows that Internet users in Indonesia have the following characteristics: the majority of Internet users use the Internet to access social media, the next rank is doing the buying and selling online, and then to support the learning activity, do instant messaging and searching for health information and health services. It is raising a new challenge for civic education which seeks to prepare citizens becomes good and smart citizens. Civic education is one of study which taken national mission to develop the nation intellectual life through value based education. Civic education which have behavioral ontology citizens can be addressed as the educational value of civic education can be used as a medium to counteract these impacts by always civilizing values that exist in order to create a good and smart citizen. Given that in Indonesia frequent cases of lawsuits related to defamation via social networking, it's appropriate if citizens are given the knowledge about the use of information technology and the sides of the law. This can be done through civic education. Citizens are expected to be more cautious and adhering to the norms when utilizing the internet.
\end{abstract}

Keyword: impact, ICT, and civic education

\section{INTRODUCTION}

The development of information and communication technologies is so rapid in some last decade. It has brought major changes to human life. At this time cannot be denied that we cannot be separated from these technologies. Our daily activity will be contacted with these technologies such as sending or receiving e-mail, send a message through social media, search the internet and so on. The development of the
Internet in Indonesia began in the 1990s which showed that internet users increased from year to year.

Indonesian internet users in 2010 amounted to 42 million, with a population of 238.5 million. It shows that the penetration was $17.6 \%$. Then in 2011 internet users increased to 55 million, with a population of 242 million, which means there is a penetration of $22.7 \%$. The next year to 63 million internet users in a population of 245.5 million, which means there is penetration about $24.23 \%$. In 2013 Internet users increased to 71.2 million, with a population of 248.9 million, which means there is $28 \%$ penetration. Then in 2014 into 88.1 million internet users with a population of 252.4 million, which means there is a penetration of $34.9 \%$ (APJII, 2014) [1]. The data show that the needs of the Internet are increasing from year to year.

The majority of internet users in Indonesia are aged between 18-25 years. It's almost half of the total number of Internet users in Indonesia, namely by 49\% (APJII, 2014) [1]. This illustrates that the segment of Internet users in Indonesia are those that are included in the category of digital native. digital native are young people who have grown up around digital technologies and seem instinctively understand the technology [2]. These categories have the characteristics of a very active use of digital technology and have the skills to operate the internet based technology. Domination performed by the digital native will create its own trend when compared to previous generation which thinking that the internet as a tool to run the work.

Most internet users in Indonesia access the internet via mobile phone. While data APJII shows that social networking became first in terms of being accessed by internet users. The next sequence is the search information (browsing / searching) then cut (messaging) (APJII, 2014) [1] 


\section{IMPACT OF INFORMATION AND COMMUNICATION TECHNOLOGY TO THE CITIZENS}

The development of information and communication technologies are so large gives extensive influence on all areas of life throughout the world, including Indonesia. Since the Indonesian government to develop the infrastructure of the internet in the 1980s the number of internet users continues to increase. It is undeniable that the presence of the internet in our daily activities give us much benefit. The internet presence has an impact on the behavior of citizens. The effects of the internet presence consist of positive and negative impact.

The positive impact of the presence of the internet which appears among others in the fields of economy, education and communication. APJII (2014) notes that internet users in Indonesia as much as $29.9 \%$ are used for open social networks. Then $20.7 \%$ was used to perform the activity of buying and selling goods and services [1]. A total of 13, 7\% used for learning activities and $7.2 \%$ to the instant messaging while the rest uses the internet to search for health information or health services as much as $5.5 \%$

Based on these data, we can know that in the economic field where the internet has provided opportunities for businesses to conduct trade. The internet can be used as a medium for marketing goods or services belong to the seller. On the other hand, the buyer finds it easy to obtain goods or services they need without having bothered to go anywhere. Then in education field the presence of the internet can be used students to acquire learning resources, instructional media and so on. In the field of communication, the internet makes communication without distance because we can easily communicate with others without being bound by space and time. This is evidenced by the rise of social networking trends. The majority of internet users use social networking to communicate.

While the negative impact caused by the internet is the spread of the internet among other pornographic content, and the number of cases of criminal defamation charges. Defamation among others: Prita detained for email service complaint against Omni International Hospital incorrect diagnosis. Complaint in August 2008 by letter and e-mail reader then circulated to the mailing list. Then Florence Sihombing, postgraduate student of UGM was detained by Yogyakarta police investigators in insulting Yogyakarta through social media Path in September 2014. Very famous pornography case happens in 2010 when Ariel which vocalist one of the Indonesia bands arrested because his personal video recording containing sexual activity with his girlfriend spread in internet after the laptop that he uses to keep his own porn video is lost due to theft.

Thus the internet, like a double-edged sword. On one side of the positive impact that can provide a huge benefit for humans when administered as well as possible. On the other hand, also brought a negative impact. Therefore, we need some stimulant for citizens in order to utilize the internet for good and was able to eliminate the negative impacts.

\section{CHALLENGES FOR CIVIC EDUCATION}

Every country has aspirations of its citizens in the future, then the setup is done through educational programs for citizens who intended to make every citizen to become a citizen as expected by the state. Civic education is one manifestation of that program. This causes differences in civic education between one state to another. Although besides it there are other differentiating factors such as the historical development of the nation, the development of educational philosophy and educational psychology. citizenship or citizenship education is construed broadly to encompass the preparation of young people for their roles and responsibilities as citizen and, in particular, the role of education (through schooling, teaching, and learning) in that preparatory process [3].

Civic education aimed at forming a good citizen. Then what is a good citizen? Good citizens are citizens that patriotic, tolerant, faithful to the nation and state, religion, democracy, true Pancasila [4]. a good citizen is a citizen who understands and able to perform well their rights and obligations as an individual citizen has a sensitivity and social responsibility [5], able to solve its own problems and the problems of society intelligently according to the functions and roles, have an attitude of self-discipline, capable of critical thinking creative and innovative in order to achieve personal qualities and behavior of citizens and residents of the community are good. [6] states good and smart citizens are citizens who master the issues supported by the civic competence which consist of adequate civic knowledge, civic disposition and civic skill, committed to the implementation of the ideals, values, concepts and democratic principles for prosperity and fairness, and responsibilities as citizens in the accomplishment of its participation in the creation and implementation of public policy. The object of civic education is citizens in association with community organizations, social, economic, religious, cultural and state [4]. the essence of the object of study of civic education is the behavior of citizens. The behavior of citizens is highly contextual, the study of civic education in a context where the citizens live and be. Its context is behavior that exhibited by individuals in the atmosphere or certain conditions. For example, how an individual as a citizen when he behaved in the house because he was a member of the family; in the context of the use of the internet how individuals behave, think, act as members of the digital community because he is a citizen of digits and so on.

With regard to the impact the development of information and communication technology is a new challenge for civic education because civic education is the education of nationality or national character education. According to Law No. 20 of 2003 on the National Education System that national education serves to develop the ability and character development and civilization of dignity in the context of the intellectual life of the nation, aims to develop students' potentials to become religious and devoted to God Almighty, noble, healthy, knowledgeable, capable, creative, independent, and become citizens of a democratic and responsible. The definition of smart is not only rational, intelligent but also emotional intelligence, social intelligence, and spiritual 
intelligence [7] [6]. Therefore, the educational process is not biased separated from the civilizing process that will deliver people into human cultured and civilized. The cultivation is a process of development of values, norms and morals within the individual through the process of engaging learners in the educational process which is an integral part of the process of Indonesian culture. It is appropriate when education is not only an educational process of thinking, but also the education of values, character and behavior. Indonesia value education in curricular integrated among others in religious education, Pancasila and civic education, language education and the arts. Civic education is a subject that is laden with social values. Values education consists of substance and process of development value to create smart and good citizen. This civic education has a role to cultivate the values in their students so it will affect the behavior of citizens.

\section{REFERENCES}

[1] APJII, Profil Pengguna Internet Indonesia 2014, Puskakom UI, Jakarta, 2015

[2] Ribble, Mike and Bailey, Gerald D, Digital Citizenship in School, International Society for Technology in Education, Eugene, Oregon, Washington DC, 2007.

[3] Kerr, D (1999) Citizenship Education In The Curriculum: An International Review, The School Field, X (3/4), 5-32

[4] Somantri, Nu'man, Menggagas Pembaharuan Pendidikan IPS, Dedi Supriyadi \& Rohmat Mulyana, Bandung: PPS-FPIPS UPI, PT Remaja Rosda Karya

[5] Wahab,Aziz and Sapriya, Teori \& Landasan Pendidikan Kewarganegaraan, Alfabeta, Bandung, 2011.

[6] Winataputra, Budimansyah; Civic Education Konteks, Landasan, Bahan Ajar dan Kultur Kelas, Prodi PKN UPI, 2007.

[7] Sanusi, A, Memberdayakan Masyarakat dalam Pelaksanaan 10 Pilar Demokrasi, Bandung: Panitia Semlok PPKN IKIP Bandung (Makalah) 